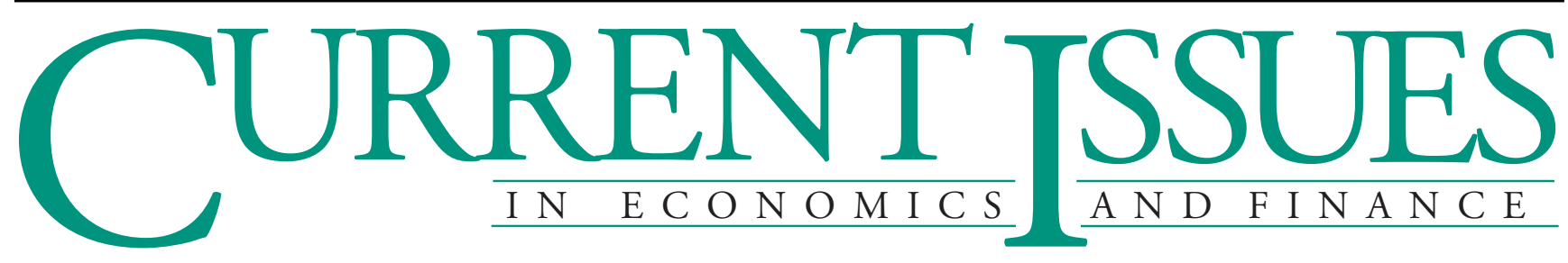

\title{
Viewing the Current Account Deficit as a Capital Inflow
}

\author{
Matthew Higgins and Thomas Klitgaard
}

With the 1998 current account deficit approaching \$225 billion, attention is again focusing on the deficit's impact on U.S. jobs. Although a high deficit does adversely affect employment in export-and import-competing industries, it also means that considerable foreign capital is flowing into the United States, supporting domestic investment spending that stimulates growth and creates jobs.

The 1998 jump in the U.S. current account deficit- the broadest measure of the trade deficit-to nearly \$225 billion is prompting concerns that American jobs are in jeopardy. ${ }^{1}$ Increasing competition in the domestic market from low-cost Asian imports could put pressure on U.S. firms to lay off workers. Exporters whose sales decline as the strong dollar raises the price of their goods in foreign markets could also move to restrict employment. Finally, jobs in export-oriented firms have been hurt by the recession in Asia, which has weakened demand for U.S. goods.

Adding to concerns about the employment effects of the current account deficit is the fear that increasing numbers of U.S. firms will shut down domestic operations and shift production to other countries, largely to take advantage of lower labor costs. In fact, some observers worry that the dollar's recent strength against Asian currencies may induce U.S. firms to buy Asian manufacturing plants at fire-sale prices, leaving fewer jobs for U.S. workers.

Nevertheless, while export and import trends support concerns about U.S. job losses, employment statistics do not bear out the relationship between a rising current account deficit and lower employment. During the 1990s, the unemployment rate has declined steadily, reaching a twenty-five-year low this year, while the current account deficit has mounted. Are the concerns over U.S. job losses from international trade misplaced?
In this edition of Current Issues, we argue that the U.S. current account deficit is not a threat to employment for the economy as a whole. When viewed narrowly as the gap between exports and imports, the current account deficit translates into lower employment in export- and import-competing industries. However, when seen from an economywide perspective, the deficit represents an inflow of employment-generating foreign investment capital to the United States. Given the low level of domestic private saving in recent years, U.S. economic growth would likely be choked off by higher interest rates and reduced investment spending if the nation had no access to this capital.

How International Capital Flows Affect U.S. Employment The debate over the North American Free Trade Agreement (NAFTA) highlighted worries that economic globalization could lower domestic employment. A particular concern was that the lower trade barriers mandated by NAFTA and other trade agreements would make it easier for U.S. firms to shut down domestic plants and move operations abroad. The goods produced abroad would then be sold in foreign markets or shipped back to the United States, with both actions tending to boost the U.S. current account deficit and reduce U.S. employment. While the NAFTA debate has receded from the headlines, the possibility that an employer will relocate overseas remains a legitimate worry for many U.S. workers. 
Foreign direct investment (FDI) data appear to support this concern. FDI is a broad measure that captures U.S. ownership of foreign business enterprises. ${ }^{2}$ At the end of 1997, U.S. foreign direct investment assets had jumped to $\$ 1,794$ billion (valued at the current market price), up from $\$ 732$ billion in 1990. U.S. holdings in the developing world-whose low-cost producers have been the focus of much of the job-loss fearsaccounted for roughly 40 percent of this total. In 1997 alone, investment funds flowing out of the United States reached $\$ 122$ billion, an amount equal to more than 14 percent of investment spending by U.S. firms.

The sheer size of foreign operations of U.S. multinational corporations also contributes to concern over foreign direct investment. In 1996, nonbank, majorityowned U.S. affiliates employed 6 million people abroad, with less than half working in the developing world. The value-added output from these operations totaled \$498 billion, \$125 billion of which was generated in the developing world. These figures suggest that U.S. multinationals today produce more than $\$ 500$ billion in goods and services abroad, rather than manufacturing them in the United States.

In assessing the impact of international capital flows on U.S. employment, however, one must consider the offsetting role played by foreign investment in the United States. As of 1996, nonbank U.S. affiliates of foreign firms employed 5 million workers here, and production totaled $\$ 340$ billion. By the end of 1997 , total foreign direct investment assets in the United States stood at \$1,621 billion, with the United Kingdom emerging as the largest source of these funds, followed by Canada and Japan. In 1997, the flow of FDI funds into the United States totaled $\$ 93$ billion. After subtracting this total from the $\$ 122$ billion flowing out of the United States, one finds that the 1997 net outflow of FDI funds, although the largest on record, amounted to only $\$ 29$ billion, or 3.3 percent of domestic business investment spending.

Other types of capital outflow from the United States are also offset by funds entering the country. Capital leaves the country in the form of portfolio investmentthe purchase of foreign government or corporate bonds, or of an equity stake of less than 10 percent in a foreign business - and banking transactions. Bringing together foreign direct investment, portfolio investment, and banking and miscellaneous transactions, we find that U.S. residents invested a total of $\$ 478$ billion abroad in 1997 . At the same time, foreign residents invested some $\$ 733$ billion in the United States, resulting in a net investment inflow of nearly $\$ 255$ billion. Thus, the U.S. economy is the net recipient of international investment capital. ${ }^{3}$

These simple calculations suggest that concerns about the employment effects of foreign direct invest- ment, or investment abroad more generally, may be misplaced. Instead, concerns about the employment effects of the trade deficit might more logically focus on the imbalance in the level of imports and exports. Although U.S. sales abroad support domestic employment, U.S. imports are far higher and they displace domestic production and lower employment. ${ }^{4}$ Indeed, one study places the net U.S. job loss due to the merchandise trade deficit at 2.4 million in $1994 .^{5}$

These seemingly conflicting findings lead us to ask an important question: What is the relationship between the large U.S. current account deficit and the nation's status as a net recipient of employment-promoting foreign investment capital?

\section{Translating the Current Account Balance into Capital Flows}

The national income accounts, which are used to calculate GDP, provide a useful framework for analyzing the connection between the current account balance and net capital flows and, in turn, their relationship to domestic saving and investment. National income accounting shows that the current account balance is related to domestic saving and investment spending in the following way:

\section{(1) current account balance $=$ domestic saving - domestic investment.}

The box offers a more detailed derivation of this relationship. In equation 1, domestic saving is the sum of private saving and government saving. Private saving comprises both individuals' saving and corporations' retained earnings, while government saving refers to tax receipts less expenditure on current goods and services. ${ }^{6}$ Domestic investment is private investment plus government infrastructure expenditure. Equation 1, in essence, defines the current account balance as the savings gap - that is, the difference between domestic saving and domestic investment spending.

The national income accounts also reveal that a country's overseas investment is related to domestic saving and investment spending as follows:

(2) net foreign asset purchases = domestic saving domestic investment. ${ }^{7}$

Simply put, a country invests abroad when its domestic savings are more than sufficient to finance domestic investment expenditure. Such a country sends its surplus savings abroad in the form of foreign direct investment or investment in foreign stocks, bonds, or real estate. This stream of surplus savings is referred to as a capital outflow, making the country a net lender to the world. A country that does not generate savings sufficient to finance its own investment needs must attract surplus foreign savings in the form of a capital 
inflow. Such a country records negative net foreign asset purchases, or equivalently, is a net borrower from the world.

The fact that the right-hand side of equation 2 is identical to the right-hand side of equation 1 implies that a current account surplus is matched by an equal net outflow of investment funds overseas, while a deficit is matched by an equal net inflow of foreign investment funds. The identification of the current account balance with net purchases of foreign assets makes considerable sense: a country is in effect lending to the world when the value of the goods it sells abroad (exports) exceeds the value of the goods it purchases (imports). Such a country accepts foreign IOUs, in the form of increased holdings of foreign assets, to bridge the gap between the value of exports and imports. Therefore, the current account balance and foreign asset purchases are simply two ways of looking at the same underlying quantity of lending. ${ }^{8}$

We stress that this view of the current account balance as equivalent to the savings gap - the difference between domestic saving and investment spending-is not a theory of how the balance is determined. ${ }^{9}$ As a result, the view involves no claims about how other economic variables, such as exchange rates, adjust to pre-

\section{Saving, Investment, and the Current Account Balance}

Using national income accounting, we can demonstrate how the equivalence of the current account balance and net capital inflows arises. Specifically, the national income accounts treat gross national product (GNP) as the sum of income derived from producing goods and services under the following categories: private consumption $(\mathrm{C})$, private investment $\left(\mathrm{I}_{\mathrm{p}}\right)$, government goods and services $(\mathrm{G})$, and exports $(\mathrm{X})$. Imports $(\mathrm{M})$ are treated as a negative item to avoid the double counting of consumption or investment goods purchased at home but produced abroad. Thus, GNP is given by

$$
\mathrm{GNP}=\mathrm{C}+\mathrm{I}_{\mathrm{p}}+\mathrm{G}+\mathrm{X}-\mathrm{M},
$$

with $\mathrm{X}-\mathrm{M}$ representing net exports plus net factor income. ${ }^{\mathrm{a}}$

A second basic equation in the national income accounts is based on the insight that any income received by individuals has four possible uses: it can be consumed $(C)$, saved $\left(\mathrm{S}_{\mathrm{p}}\right.$, for private savings), paid in taxes $(\mathrm{T})$, or transferred abroad (Tr). Because GNP is simply the sum of the income received by all individuals in the economy, we have

$$
\mathrm{GNP}=\mathrm{C}+\mathrm{S}_{\mathrm{p}}+\mathrm{T}+\mathrm{Tr} .
$$

By equating the two expressions for GNP developed above, canceling out $\mathrm{C}$, and rearranging terms, we derive the following equation: serve the equality of the savings gap and the current account balance. However, the savings-gap perspective does offer a grounding for trade policy debates. In particular, any argument about the behavior of a country's current account balance should be reconciled with a plausible argument about the behavior of the gap between saving and investment spending.

\section{The Need for Foreign Capital}

The connection between the current account balance and net capital flows, as specified in the savings-gap view, sheds light on the issues surrounding international trade and employment. A high current account deficit may indeed hurt employment in particular firms and industries as workers are displaced by increased imports or by the relocation of production abroad. At the economywide level, however, the current account deficit is matched by an equal inflow of foreign capital, which finances employment-sustaining investment spending that would not otherwise occur. ${ }^{10}$

To clarify this point, we consider the behavior of the U.S. current account in the 1990s. The current account deficit has climbed steadily during the country's recent economic expansion, but so has domestic employment: the unemployment rate now stands near its twenty-five-

$$
X-M-T r=\left(S_{p}-I_{p}\right)+(T-G),
$$

with $\mathrm{X}-\mathrm{M}$ - Tr equaling the current account.

In other words, the current account balance is equal to the surplus of private savings over investment and the gap between government tax receipts and government expenditure on goods and services, that is, the government budget surplus.

A final equation is needed to clarify the link between the current account balance and the net flow of foreign investment capital. A dollar of savings can be classified according to the type of asset it buys. In particular, the dollar can be used to purchase domestic physical capital, domestic government debt, or a foreign asset (FA) of some sort. Recalling that net issuance of government debt is equal to the government budget deficit, $\mathrm{G}$ - T, we have

$$
\mathrm{S}_{\mathrm{p}}=\mathrm{I}_{\mathrm{p}}+(\mathrm{G}-\mathrm{T})+\mathrm{FA} \text {. }
$$

Rearranging, we have

$$
\mathrm{FA}=\left(\mathrm{S}_{\mathrm{p}}-\mathrm{I}_{\mathrm{p}}\right)+(\mathrm{G}-\mathrm{T}) \rightarrow \mathrm{FA}=\mathrm{X}-\mathrm{M} .
$$

This last equation can be interpreted as representing the fact that a country accumulates foreign assets (or equivalently, is a net lender to the rest of the world) when domestic private saving is more than sufficient to finance private investment spending plus the government budget deficit.

${ }^{a} \mathrm{Net}$ factor income captures the returns on domestic and foreign assets. 


\section{Chart 1}

\section{U.S. Investment and Saving}

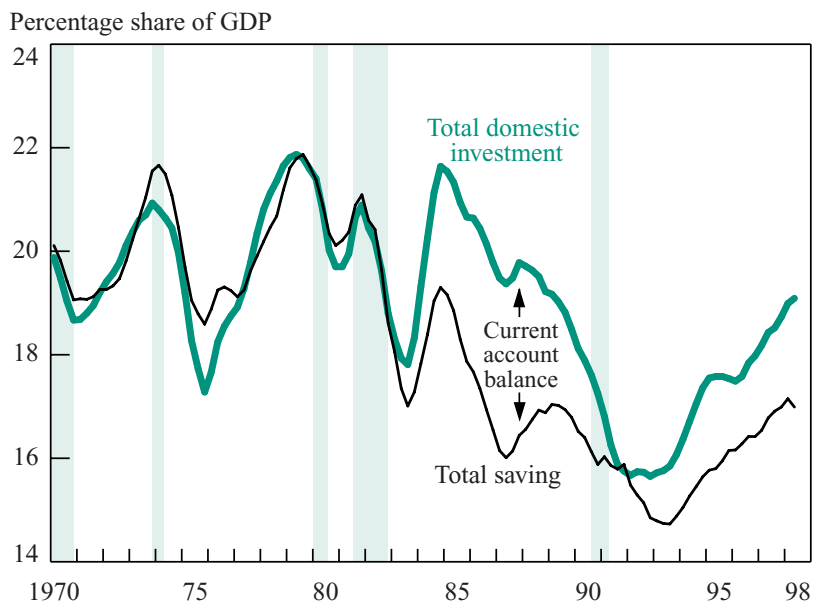

Source: U.S. Department of Commerce, Bureau of Economic Analysis.

Notes: The share of nominal GDP is calculated as a four-quarter moving average. The gap between investment and saving is the current account adjusted for national income accounts data coverage. Private saving and investment have been adjusted to compensate for statistical discrepancies between the savings gap and net foreign investment. The shaded areas denote periods designated recessions by the NBER

year low. From an economywide perspective, the deterioration in the current account balance is being driven by an increase in domestic investment and a fall in saving as shares of GDP (Chart 1). The shortfall in domestic saving means that the increase in investment spending, and the robust job growth associated with it, could only be financed through foreign saving, in the form of a capital inflow to the United States. Accordingly, the country's high current account deficit can be viewed as a reflection of this need for foreign capital to sustain the economy.

The discussion thus far has emphasized changes in saving and investment as the primary forces driving the U.S. current account balance. However, this argument does not imply that domestic factors alone can affect the current account balance. Foreign developments can also indirectly affect domestic saving and investment behavior. A recent example is the recession in Japan, which reduced U.S. sales to that country and boosted Japanese sales to the United States (to the extent that the recession weakened the yen). ${ }^{11}$ However, the recession also brought a sharp slump in Japan's domestic investment spending and thus an increase in the flow of surplus Japanese savings to the world. The increased capital outflow from Japan placed downward pressure on world and U.S. interest rates, which helped boost U.S. investment and consequently limited the Japanese recession's negative fallout on U.S. employment.

\section{The Growing Foreign Debt Burden}

The current account deficit allows the United States to maintain a higher rate of investment spending than would be possible by relying on domestically generated savings alone. However, the corresponding foreign capital inflow is essentially a loan; therefore, it represents claims on future national income. Before the 1980s, the United States was a net lender to the world. In subsequent years, however, large current account deficits brought total U.S. indebtedness to $\$ 1.3$ trillion by the end of 1997 , or a little more than 12 percent of GDP. ${ }^{12}$ Going forward, a continuation of these large deficits would cause foreign indebtedness as a share of GDP to rise rapidly. ${ }^{13}$

Whether current account deficits and the associated foreign debt burden represent a policy concern depends on one's view of the trade-off between higher investment and higher external indebtedness. One school of thought holds that the source of the deficit lies in a favorable U.S. investment climate, which acts as a magnet for foreign capital. According to this view, foreign investment funds raise the U.S. capital stock. By boosting future U.S. GDP, the higher capital stock makes it easier for the nation to pay off the higher foreign debt.

The Savings Gap and the Current Account Balance

\begin{tabular}{|c|c|c|}
\hline & 1992 & 1997 \\
\hline Private saving & $\begin{array}{l}\$ 993 \text { billion } \\
\quad(15.9)\end{array}$ & $\begin{array}{c}\$ 1,114 \text { billion } \\
(13.7)\end{array}$ \\
\hline Government budget balance & $\begin{array}{c}-\$ 276 \text { billion } \\
\quad(-4.4)\end{array}$ & $\begin{array}{l}\text { \$29 billion } \\
\quad(0.4)\end{array}$ \\
\hline \multicolumn{3}{|l|}{ equals } \\
\hline Subtotal & $\begin{array}{l}\text { \$718 billion } \\
\quad(11.5)\end{array}$ & $\begin{array}{l}\$ 1,143 \text { billion } \\
(14.1)\end{array}$ \\
\hline $\begin{array}{l}\text { less } \\
\text { Private domestic investment }\end{array}$ & $\begin{array}{c}768 \text { billion } \\
(12.3)\end{array}$ & $\begin{array}{l}\$ 1,284 \text { billion } \\
(15.8)\end{array}$ \\
\hline \multicolumn{3}{|l|}{ equals } \\
\hline Net foreign investment & $\begin{array}{l}-\$ 50 \text { billion } \\
\quad(-0.8)\end{array}$ & $\begin{array}{c}-\$ 141 \text { billion } \\
(-1.7)\end{array}$ \\
\hline \multicolumn{3}{|l|}{ plus } \\
\hline Statistical adjustment & $\begin{array}{l}-\$ 1 \text { billion } \\
\quad(0.0)\end{array}$ & $\begin{array}{l}-\$ 14 \text { billion } \\
\quad(-0.2)\end{array}$ \\
\hline \multicolumn{3}{|l|}{ equals } \\
\hline Current account balance & $\begin{array}{l}-\$ 51 \text { billion } \\
\quad(-0.8)\end{array}$ & $\begin{array}{c}-\$ 155 \text { billion } \\
(-1.9)\end{array}$ \\
\hline \multicolumn{3}{|l|}{ Memo: } \\
\hline Unemployment rate & 7.4 percent & 5.0 percent \\
\hline
\end{tabular}

Source: U.S. Department of Commerce, Bureau of Economic Analysis, National Income and Product Accounts and Balance of Payments Accounts.

Notes: Figures in parentheses are percentages of nominal GDP. Private saving and investment have been adjusted to compensate for statistical discrepancies between the savings gap and net foreign investment. The statistical adjustment reflects differences in how national income accounts and balance of payments data are calculated. Figures may not sum to totals because of rounding. 
A less sanguine view is that the source of the deficit lies in an anemic U.S. saving rate, which forces the country to rely on foreign capital to maintain its current level of investment. ${ }^{14}$

Despite their differences, proponents of both views would agree that to slow the accumulation of foreign debt without reducing investment spending, the United States has to raise its saving rate, either through increased private saving or through further improvements in the government budget balance. Studies have shown that policies aimed at promoting private saving through tax incentives have had little success, leaving the budget balance as the most direct policy tool for raising national saving. ${ }^{15}$

The federal government has been successful in increasing national saving by eliminating the budget deficit. However, these efforts have been blurred by offsetting developments. The government budget balance and the current account balance deteriorated together in the 1980s, prompting analysts to label them the "twin deficits." But in the 1990s, the two balances have moved in opposite directions. The government balance went from a $\$ 276$ billion deficit in 1992 to a surplus of \$29 billion in 1997, while the current account deficit swelled from $\$ 51$ billion to $\$ 155$ billion (see table). ${ }^{16}$ The elimination of the government budget deficit by itself would have freed sufficient savings to finance the recovery in investment spending following the recession of the early 1990s. The continued decline in

\section{Chart 2}

\section{Private Saving and the Government Balance}

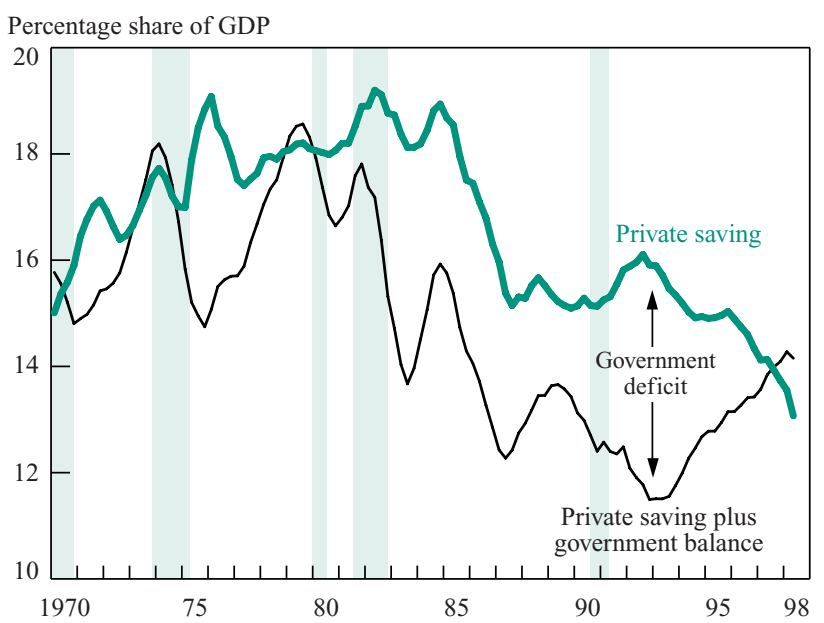

Source: U.S. Department of Commerce, Bureau of Economic Analysis.

Notes: The share of nominal GDP is calculated as a four-quarter moving average. Private saving has been adjusted to compensate for statistical discrepancies between the savings gap and net foreign investment. The shaded areas denote periods designated recessions by the NBER. private saving as a share of GDP, however, meant that the recovery had to be financed in part through increased foreign borrowing (Chart 2). So while it is not evident from the performance of the U.S. current account balance, the federal government has helped slow the increase in foreign indebtedness by eliminating its need to borrow from the domestic savings pool.

\section{Conclusion}

Viewing the current account deficit as a capital inflow helps to dispel misconceptions about the consequences of economic globalization. The current account deficit, seen as the net balance in the trade of goods and services, does translate into fewer jobs in export- and import-competing firms and industries. Yet when viewed as the net inflow of foreign investment capital, the current account deficit produces jobs for the economy as a whole: both from the direct effects of higher employment in investment-oriented industries and from the indirect effects of higher investment spending on economywide employment. Increased investment spending, however, comes at the cost of greater foreign debt. The federal government has done its part to slow the accumulation of debt by eliminating the budget deficit, an action that helps ensure the productive use of the foreign capital inflow. Nevertheless, because of the downward trend in private saving, the United States must continue to rely on foreign capital to maintain an adequate rate of investment spending.

\section{Notes}

1. The current account includes imports and exports of goods and services, net payments for factor services such as interest on securities, and profits from foreign direct investment. In addition, it includes net transfers such as government payments of social security to U.S. citizens living abroad.

2. The foreign ownership stake must be 10 percent or more. Purchases of real estate are also included in FDI.

3. Note that flows outside the FDI category indirectly support domestic investment spending because of the fungibility of investment funds. For example, the purchase of U.S. government debt by foreign residents frees up an equal amount of domestically generated saving to support plant and equipment investment.

4. The U.S. Commerce Department uses a detailed input-output table to calculate the number of full-time jobs directly and indirectly based on exports. (A job is considered to be indirectly based on exports when it involves providing intermediate parts or supplies to the exporting firm.) The Department's most recent report (Davis 1996) finds that exports of merchandise support 6.8 million jobs and exports of services support an additional 3.5 million jobs. The Commerce Department does not conduct a similar analysis of jobs lost because of imports.

5. This study (Scott, Lee, and Schmitt 1997) reaches a conclusion that seems plausible. However, the results become less intuitive 
when one considers that adding back the jobs "lost" from the trade deficit would drop the national unemployment rate to near 2.0 percent in 1998, a rate far below any value observed in the postwar era.

6. Government saving is equal to the government budget balance plus government infrastructure investment.

7. Net foreign asset purchases refer to purchases of foreign assets by U.S. residents less purchases of U.S. assets by foreign residents. These purchases in both directions are themselves net purchases, that is, purchases by U.S. residents of additional foreign assets less sales of current foreign asset holdings.

8. In theory, the capital account, which tracks asset purchases between countries, should match the current account. In practice, the two usually differ because of statistical discrepancies.

9. In particular, equations 1 and 2 are identities, that is, they are true by definition. Equation 1, for example, does not make any empirical claim about the determination of GDP; rather, it is simply a way of classifying GDP according to the type of good produced. Similarly, equation 2 is simply a way of classifying GDP according to the use made of income.

10. It is not possible to compute the net employment effects of the current account deficit - that is, the difference between the number of jobs lost from net trade flows and the number supported by the corresponding foreign capital inflow. The current account deficit and matching capital inflow are, of course, exactly equal in dollar terms. However, we have no clear basis for specifying the counterfactual saving and investment flows that would hold in the absence of a current account deficit. The employment effects of eliminating the deficit by increasing domestic saving - and thus reducing consumption spending - might well be different from the employment effects of eliminating the deficit by reducing investment spending.

11. The result has been a higher bilateral trade deficit with Japan. By itself, a higher bilateral deficit need not lead to an increase in the overall U.S. current account deficit.

12. Despite the United States' position as a net debtor, earnings on its international investment portfolio have often exceeded the corresponding payments abroad during the 1990s. The reason, in part, is that the United States earns a much higher rate of return on its foreign direct investment holdings than foreign residents earn on their direct investments in the United States. In 1997, U.S. residents earned an average rate of return of 10.9 percent on their holdings abroad, while foreign residents earned 5.8 percent on their U.S. holdings (U.S. Department of Commerce, Bureau of Economic Analysis).

13. For example, a persistent current account deficit equal to 2 percent of GDP would push the foreign debt/GDP ratio past 40 percent by 2020 and past 50 percent by 2045 . (This calculation assumes a trend-nominal GDP growth rate of 5 percent.)

14. This view presupposes some sort of market failure (for example, a lack of information about the future consequences of maintaining today's low saving rate) that prevents U.S. residents from saving as much as they should.

15. For example, McCarthy and Pham (1995) discuss the limited effectiveness of individual retirement accounts in raising national saving.

16. In theory, net capital inflows to the United States always equal the U.S. current account deficit. In practice, the two amounts sometimes differ because of problems in data gathering. For example, the failure to track all capital inflows to the United States would cause net capital inflows to be different from the current account. In 1997, the discrepancy attributed to such data-gathering problems was roughly $\$ 100$ billion, an amount almost twice as big as the previous record. Thus, the 1997 U.S. current account deficit of $\$ 155$ billion differed by $\$ 100$ billion from the $\$ 255$ billion recorded as the net investment inflow.

\section{References}

Davis, Lester. 1996. "U.S. Jobs Supported by Goods and Services Exports, 1983-94.” U.S. Department of Commerce Research Series OMA-1-96.

McCarthy, Jonathan, and Han Pham. 1995. "The Impact of Individual Retirement Accounts on Savings." Federal Reserve Bank of New York Current Issues in Economics and Finance 1, no. 6 .

Scott, Robert, Thea Lee, and John Schmitt. 1997. Trading Away Good Jobs: An Examination of Employment and Wages in the U.S., 1979-94. Washington, D.C.: Economic Policy Institute.

\section{About the Authors}

Matthew Higgins and Thomas Klitgaard are senior economists in the International Research Function of the Research and Market Analysis Group.

The views expressed in this article are those of the authors and do not necessarily reflect the position of the Federal Reserve Bank of New York or the Federal Reserve System.

Current Issues in Economics and Finance is published by the Research and Market Analysis Group of the Federal Reserve Bank of New York. Dorothy Meadow Sobol is the editor.

Subscriptions to Current Issues are free. Write to the Public Information Department, Federal Reserve Bank of New York, 33 Liberty Street, New York, N.Y. 10045-0001, or call 212-720-6134. Current Issues is also available at the Research and Market Analysis Group's web site: http://www.ny.frb.org/rmaghome/curr_iss/1998.htm. 